Journal of Teacher Education for Sustainability, vol. 20, no. 1, pp. 64-81, 2018

\title{
Implementing Education for Sustainable Development in Namibia: School Teachers' Perceptions and Teaching Practices
}

\author{
Eveline O. Anyolo \\ University of Namibia, Windhoek, Namibia \\ Sirpa Kärkkäinen and Tuula Keinonen \\ University of Eastern Finland, Joensuu, Finland
}

\begin{abstract}
Education for Sustainable Development (ESD) has been viewed as education that helps people develop the attitude, skills, and knowledge to make well-informed decisions for the benefit of the present and future generations. It aims at providing quality education through shared understanding and multi-disciplinary approaches in meeting the developmental and environmental apprehension for a sustainable future. Many theorists envisaged ESD as enhancing active involvement of learners both in school and out of school learning initiatives to acquire knowledge about sustainable development issues. The present paper discusses Namibian school teachers' $(n=9)$ perceptions of ESD and the teachers' teaching practices using a qualitative-explorative study design. The data were gathered through two semi-structured interviews and lesson observations. The findings have revealed that senior secondary school teachers perceive ESD in terms of knowledge acquisition about the environment in order to use its resources sustainably for the benefit of future generations. The study has also revealed that teachers have positive sentiment toward the inclusion of ESD into the senior secondary school curriculum. Following this, they suggested that ESD should be either implemented as an independent subject or integrated with other existing subjects as a multi-disciplinary subject.
\end{abstract}

Keywords: education for sustainable development, implementation of education for sustainable development, teachers' perceptions, secondary school

\section{Introduction}

Education for Sustainable Development (ESD) is concerned with equipping individuals, communities, and governments to live and act sustainably and understand environmental, social, and economic aspects of sustainable development (Reid, 2002). It focuses on improving the quality of the environment, quality of life, and a more equitable economic growth for sustainability. A sustainable society requires healthy, well-educated, skilled, 
and active citizens that are informed and motivated to live more sustainably and ensure future generations' quality of life (e.g., Biasutti, De Baz, \& Alshawa, 2016; Carban \& Fisher, 2017). Therefore, both affective and cognitive aspects of learning should be incorporated in ESD (Littledyke, 2008). Sustainability can be seen as a goal for ESD akin to Sustainability Education (SE), which is used synonymously in the present study. The goal of ESD is to educate and train students for sustainable decision-making in future through social learning, a special form of transformative learning (Wals, 2011). Teachers have the responsibility to help learners develop and address the knowledge and skills needed to enable them to understand complex sustainable development issues, and sustainability challenges facing society (Hungerford, 2010). Successful learning in ESD is closely related to methods used by the teachers and learners (Abdulwali, Alshmrani, \& Almufti, 2017; Kostova \& Atasoy, 2008; Olsson, Gericke, \& Chang Rundgren, 2016; Ortega \& Fuentes, 2015; van Gejeka, 2013). However, many teachers feel underprepared as they lack knowledge in ESD (Summers, Childs, \& Corney, 2005; Uitto \& Saloranta, 2017). The present study examines Namibian school teachers' perceptions of ESD and how they implement ESD in teaching. In Namibia, ESD is becoming more important because of the growing economy and the number of relatively young consumers who need to learn to live sustainably. In Namibia as well as in many other African countries, educational policies, standards in education and practices in educational institutes are varying (see Egne, 2014; Ololube, Egbezor, \& Kpolovie, 2008).

Teachers' perceptions of ESD play a major role in the way they teach and prepare learners for the future. The presence of sustainability and ESD in the curriculum varies around the world and the implementation of ESD in schools and universities has been studied in several countries from different continents (e.g., Biasutti et al., 2016; Egne, 2014; Fraser, Gupta, \& Krasny, 2015; Green \& Somerville, 2015; Kimaryo, 2011; Olsson et al., 2016; Sund, 2016; Uitto \& Saloranta, 2017). North American practitioners from formal and informal institutions represented different distinct perspectives in prioritizing environmental education outcomes (Fraser et al., 2015). Green and Somerville (2015) found that Australian primary school teacher' accounts of their practice illustrate the ways they interacted with the materiality of local places as an essential part of sustainable education. They identified ESD practices within the four sets of relations: the materiality of school grounds; connections with local places; partnerships with community; and creative processes. A study carried out in Tanzania reveals that primary school teachers perceive environmental education as providing knowledge about the environment (Kimaryo, 2011). In Sweden, Olsson et al. (2016) compared different schools in relation to ESD and found differences in the effects on students' sustainability consciousness, a concept that integrates the environmental, social, and economic dimensions of sustainable development all including knowingness, attitudes and behaviour. Swedish teachers also articulated different ways of utilising the curriculum and enacting pedagogies relating to complex global issues (Sund, 2016). Contextual-historical aspects of global sustainability issues were primarily emphasised by the civics and history teachers; these teachers as well as the science teachers related to the affective aspect by considering equity, fairness and responsibility to distant others as important factors with sustainability issues (Sund, 2016). Uitto and Saloranta (2017) pointed out that subject teachers' awareness of their ESD competence was important in implementing discipline-based and interdisciplinary ESD in their teaching. In their study, every subject teacher group had its specific strengths and weakness in ESD. For instance, teachers of biology, geography, 
history and social studies and, to some extent, also religion and ethics teachers considered several but different sustainability dimensions and used holistic approaches in their sustainability-related teaching (Uitto \& Saloranta, 2017).

Holistic approach is also highlighted by Yavetz, Goldman, and Pe'er (2014). According to the scholars, teachers need to enrich their learners' knowledge about the environment and abilities to understand, criticise and participate rationally in the discourse or controversial, value-laden issues of sustainability, which require a holistic approach. Wals (2011) points out that social learning is learning by mirroring one's own ideas, views, values, and perspectives with those of different from others. Using a multi-disciplinary approach, Borg, Gericke, Höglund, and Bergman (2014) found that teachers have an understanding of the concept as a whole, i.e., they know what they are supposed to contribute in their own teaching. However, teachers have difficulties in terms of understanding the complexity of sustainable development issues, the nature and the interrelations of its sub-concepts (Corney, 2006). Teachers have also little understanding of the term "sustainability", in terms of its content and principles. As a result, they somewhat take into consideration most of the local and national issues and seem to underestimate the global ones (Spiropoulou, Antonakaki, Kontaxaki, \& Bouras, 2007). In addition, Green and Somerville (2015) reported that teachers did not understand the concept and could not integrate sustainability into an already overcrowded curriculum. To engage teachers in integrating sustainability into the curriculum, they need to be active curriculum planners themselves. Furthermore, active curriculum planners need to be equipped with adequate professional knowledge and personal practical knowledge (Kabadayi, 2016).

ESD learning methods are as follows:

1) Interdisciplinary and holistic;

2) Learner-centred and participatory;

3) Value-driven, promoting critical thinking and exploring all stakeholders;

4) Forward-looking, promoting medium and long-term planning;

5) Locally relevant, encouraging multilateral collaboration among schools, local actors, and authorities, scientific communities, private sector, and NGOs, etc. and revealing global issues and connections as part of everyday life, whether in a small village or a large city (Alampei, Malotidi, Psallidas, \& Scoullos, 2013, p.110).

The participatory active teaching methods stimulate learners to reflect on their own learning regarding sustainability (Scott, 2008). Integration of emotional approaches is particularly relevant for fostering reflective awareness at a number of levels (selfawareness, social awareness and environmental awareness). Thus, reasons and emotions can be integrated with socially or ecologically beneficial behaviour at the individual, societal and political levels (Littledyke, 2008). Participatory methods such as problemsolving, discussions, debates, presentations, fieldwork, experiments, demonstrations, projects and co-operative learning (Huckle, 2006; Ketlhoilwe, 2007; 2010; Sterling, 2001) promote competencies such as critical thinking, imagining future scenarios and making decisions in a collaborative way (Scoullos, 2013; UNESCO, 2009). For many ESD (school) programmes, fieldwork is singled out as an important approach (Corney \& Reid, 2007; Gayford, 2003; Jeronen, Palmberg, \& Yli-Panula, 2017). Jeronen et al. (2017) emphasise especially the value of inductive teaching methods with student-centred approaches in authentic environments with first-hand experiences and field trips, including 
problem-based activities, as factors increasing students' interest and knowledge of sustainability. Fieldwork appeared to have positive effects also on students' attitudes and behavior concerning sustainability (Jeronen et al., 2017). If learners are not actively involved in the environment as part of their learning, they will never be enthusiastic to the environment (Majumdar, 2012).

There seems to be a number of barriers that teachers experience in successful implementation of ESD in schools. These are a lack of time (Corney, 2006; Dube, 2012; Hartsell, 2006; Iliško, Ignatjeva, \& Mičule, 2011; Kanyimba, 2002; Simasiku, 2012; Summers et al., 2005); a lack of teachers' knowledge and skills and resources (Spork, 1992; Summers et al., 2005); and a lack of awareness and involvement in sustainable development (Velazquez, Munguia, \& Sanchez, 2005). Additionally, a lack of teaching and learning materials is among the challenges faced by the teachers in implementing ESD (Summers et al., 2005). Further, Kanyimba (2002) found resistance to change and deficiency in environmental policies as barriers that negatively affected the effective implementation of ESD. Other barriers include teachers' personality, the prevailing school climate regarding the use of teaching methods and a lack of support from the school principals (Summers et al., 2005). Many teachers are willing to develop their teaching and work in an interdisciplinary way, but they feel that they do not have time and knowledge, skills, and resources (Spork, 1992; Summers et al., 2005). In addition, educational policies, which highlight closed and subject-centred discourse, could make successful teaching about sustainable development even more problematic in the future (Dimenäs \& Alexandersson, 2012).

The ESD approach has been integrated as a cross-curricular theme in Namibian schools (Ministry of Basic Education, Sport and Culture, 1997). In 2002, the National Assessment Report testified that Namibia faced challenges in integrating ESD activities in the national programmes to ensure a sustainable future. Most teachers in Namibia are used to the traditional teaching and learning methods that take learners as passive listeners in the classrooms; thus, they resist to the change to learner-centred approach to teaching (Kasanda et al., 2005). However, teachers in Namibia as well as school managers have a partial understanding of ESD (Kanyimba, 2002). The present study produces deeper knowledge about Namibian teachers' ways to implement ESD. The following research questions have been put forward to guide the study:

- How do teachers perceive education for sustainable development?

- How do teachers perceive the integration of education for sustainable development into the school curriculum?

- What teaching strategies do teachers use in implementing education for sustainable development?

- What barriers do teachers face in implementing education for sustainable development?

\section{Methodology}

The present study is framed as qualitative research because it aims at understanding the subjective world of the human experiences (Cohen, Manion, \& Morrison, 2011) and seeks answers to questions that stress how social experience is created and the meaning that it is given (Denzin \& Lincoln, 2008). Thus, a qualitative approach is seen 
as a type of a research approach that focuses on description, interpretation and exploration of ESD and its integration into the curriculum. The use of a qualitative approach in the present study helps the researchers hear the voices and understand the feelings of teachers about the implementation of ESD in the school curriculum, as well as identify actions teachers have taken to make sure that ESD is fostered into practice. This indicates that the researchers are interested in the process, meaning and understanding gained through interacting with teachers, in order to enable the researchers to gather descriptive data.

The qualitative research follows a case study design, an empirical inquiry that investigates a contemporary phenomenon, implementation of ESD, within its real-life context, when the boundaries between phenomenon and context are not clearly evident, and which uses multiple sources of evidence (Yin, 2003; 2009) and provides an opportunity for one aspect of a problem to be studied in some depth (Bell, 2010).

\section{Participants and Setting}

Nine senior secondary school teachers ( 5 male and 4 females) from three schools in Oshana Education region were chosen through purposeful sampling for a specific purpose. The aim of purposeful sampling is to generate a sample that allows for an understanding of the social process of interest (Nigatu, 2009). The teaching experience of the sample of teachers ranges from 2 to 25 years. Five of the participants obtained a Bachelor of Education Degree (BEd) after Grade12 and four obtained a Teaching Diploma (Table 1). For a convenient reference back to the data sources; schools were allocated codes. For ethical consideration, teachers were given pseudo names.

Table 1

Teachers' Profiles

\begin{tabular}{llllll}
\hline School & $\begin{array}{l}\text { Teacher } \\
\text { (Pseudo) }\end{array}$ & Gender & \multicolumn{1}{c}{ Qualification } & \multicolumn{1}{c}{ Subject } & $\begin{array}{c}\text { Teaching } \\
\text { experiences }\end{array}$ \\
\hline S1 & Desy & Male & Post Graduate in Education & Business studies & 13 years \\
\cline { 2 - 6 } & Lily & Female & BEd Honours in Education & English & 14 years \\
\cline { 2 - 6 } & Moris & Male & BEd Honours in Education & $\begin{array}{l}\text { Biology and } \\
\text { Mathematics }\end{array}$ & 5 years \\
\cline { 2 - 6 } & Penni & Female & Diploma in Education & Biology & 2 years \\
\cline { 2 - 6 } & Pea & Female & BEd. Honours in Education & Development Studies & 25 years \\
\hline S2 & Oli & Male & Advanced Diploma in & $\begin{array}{l}\text { Biology and } \\
\text { Physical Science }\end{array}$ & 5 years \\
& Don & Male & BEd Honours in Education & Development Studies & 3 years \\
\cline { 2 - 6 } & Pius & Female & Higher Education Diploma & Agriculture & 13 years \\
\hline S3 & Radon & Male & Bachelor of Education & $\begin{array}{l}\text { Geography and } \\
\text { Development Studies }\end{array}$ & 8 years \\
\hline
\end{tabular}

The selection of schools was based on a number of criteria. Firstly, all schools are senior secondary schools. Secondly, all chosen schools are state-run schools, no private schools were chosen because some of them followed different curricula. Thirdly, the schools were chosen based on subjects or fields of studies offered. Fourthly, the locations 
of the schools were also considered. School One and school Two are located in town and cater for urban learners. School Three is located in the suburb and caters for both rural and urban learners.

\section{Data Collection and Analysis}

To answer the research questions of the study, two data collection methods (semistructured interviews and lesson observations) have been used. The choice of the methods has been influenced by the research aims and objectives.

\section{Semi-structured Interviews}

According to Willis (2007), qualitative interpretive case studies tend to use semistructured interviews and unstructured interviews, which can be conducted one-to-one or in groups. Semi-structured interviews are used to find out information from a particular group of people, or to find out their opinions (Mweti \& Van Wyk, 2005). Besides, they offer rich and more extensive data than data from surveys or even the open-ended portions of survey instruments (Yin, 2012). Accordingly, a semi-structured interview well serve the purpose of the study. More importantly, the open-ended questions used in the semi-structured interviews could allow the interviewees to provide answers at length, and the researcher to probe further.

\section{Observations}

According to Burton, Brundrett and Jones (2008, p. 97), observation is one of the most powerful tools in research, especially for researchers in social sciencesī. The purpose of observation is mainly to give the researcher direct, first-hand experience with the phenomena under study (Cantrell, 1993). Accordingly, the participants were also observed to see whether they put into practice what they said they intended to do in the interviews. Afterwards, teachers were asked to reflect on their lessons regarding integrating the aspects of sustainable development (ecological,social and economic) into their teaching. Finally, they briefly commented on their reflections.

\section{Data Analysis}

This study adopted a qualitative content analysis to analyse data from interviews and lesson observations. According to Flick (2007), content analysis is one of the procedures for analysing textual (verbal or behavioural data) materials. It involves a process designed to condense raw data into categories or themes based on inference and interpretation (Zhang \& Wildemuth, 2009). The responses from interviews were coded by making use of the Atlas-ti programme. Data from observations were manually coded. The codes were grouped into different categories and subsequently developed into themes by making use of an inductive data analysis. 


\section{Results and Discussions}

Teachers' perceptions of ESD were categorised in five themes: concept of ESD, integration of ESD into the curriculum, teaching practices in implementing ESD into the curriculum, barriers to the effective implementation of ESD, and suggestions for improving the implementation of ESD at senior secondary schools.

\section{Education for Sustainable Development}

All the nine teachers had similar understanding of sustainable development as they supposed that sustainable development was about using the resources in a sustainable way in order to benefit generations to come (cf., Spiropoulou et al., 2007). However, in their explanations, teachers did not show how sustainable development was linked to social and economic dimensions of sustainable development. Five teachers (Desy, Pea, Don, Pius and Radon) described ESD as making people aware of the environment. Lily, Moris, and Penni related ESD to caring for the environment in terms of sustaining its resources to ensure a sustainable future. Oli described ESD as education that promoted critical thinking and problem-solving skills. These types of teachers' perceptions are presented in Table 2.

Table 2

Teachers' Perceptions of Education for Sustainable Development

\begin{tabular}{lll}
\hline \multicolumn{1}{c}{ Categories } & \multicolumn{1}{c}{ Teachers } & \multicolumn{1}{c}{ Teachers' examples } \\
\hline $\begin{array}{l}\text { ESD as environmental } \\
\text { sustaining resources }\end{array}$ & $\begin{array}{l}\text { Desy, Pea, } \\
\text { Don, Pius, } \\
\text { Radon }\end{array}$ & $\begin{array}{l}\text { ESD is just to extend the environmental awareness so } \\
\text { that our learners can at least know more about the envir- } \\
\text { onment. Actually, this is just to do with the awareness, } \\
\text { to open the learners mind so that they know more about } \\
\text { their environment and that they have to sustain the natural } \\
\text { resources (Pius). }\end{array}$ \\
\hline
\end{tabular}

\begin{tabular}{lll}
\hline $\begin{array}{l}\text { ESD as education for } \\
\text { sustainable future }\end{array}$ & $\begin{array}{l}\text { Lily, Moris, } \\
\text { Penni }\end{array}$ & $\begin{array}{l}\text { ESD simply means just to educate people so that they } \\
\text { are able to wisely use what has been there so that it can } \\
\text { be used by future generations (Penni). }\end{array}$ \\
\hline $\begin{array}{l}\text { ESD as skills-focus } \\
\text { education }\end{array}$ & Oli & $\begin{array}{l}\text { ESD, I think is the kind of education that encourage or } \\
\text { promote critical-thinking and problem-solving skills, } \\
\text { being able to think about the development in a way that } \\
\text { you do not have any negative impact on the environment. }\end{array}$ \\
& $\begin{array}{l}\text { For example, if one wants to develop a country, the } \\
\text { result will be pollution, because industries will release } \\
\text { a lot of smoke into the air. So, ESD will like teach people } \\
\text { how to think critically about these issues so that they } \\
\text { do not create problems (Oli). }\end{array}$ \\
\hline
\end{tabular}

Apart from creating environmental awareness, Don and Pius stated that ESD taught about social and economic aspects and acknowledged that all aspects were important for sustainable development. In this way, they enriched their learners with more than knowledge to enable them to participate rationally in the discourse, value-laden issues of sustainability which required a holistic view in addressing social, cultural and ethical aspects (Scoullos, 2013; Wals, 2011; Yavetz et al., 2014). Affective aspects highlighted by Littledyke (2008) can be seen included in these aspects. 
ESD was also described in relation to a sustainable future by Lily, Moris and Penni. Since teachers perceived sustainable development as taking care of the resources for future generations, they also described ESD in relation to the equitable distribution of resources for the benefit of future generations Reid (2002). Teachers did not identify local places, communities or creativity as part of ESD (c.f., Green \& Somerville, 2015). Skills for maintaining life for future generations were demonstrated in Oli's perceptions of ESD as he described it in terms of critical thinking and problem-solving skill development Alempei et al. (2013). Oli is the only biology and physical science teacher; thus, there were some differences in teachers' perspectives according to their teaching subjects (Sund, 2016; Uitto \& Saloranta, 2017). However, the differences were not clear, the schools were similar, none was specialised in ESD, and no clear differences were found Olsson et al. (2016). Teachers particularly linked ESD to knowledge through resources (Kimaryo, 2011). It can be concluded that they were three slightly different perspectives on ESD: environmental awareness, sustainable future and skill-focused perspectives (Table 2, cf., Fraser et al., 2015).

\section{Integration of ESD into the Curriculum}

Teachers' perceptions of the integration of ESD into the curriculum are categorised in three categories and are shown in Table 3.

Table 3

Teachers' Perceptions of the Integration of ESD into the Curriculum

\begin{tabular}{lll}
\hline \multicolumn{1}{c}{ Categories } & \multicolumn{1}{c}{ Teachers } & \multicolumn{1}{c}{ Some teachers' examples } \\
$\begin{array}{l}\text { Teaching ESD topics } \\
\text { in different subjects }\end{array}$ & All & $\begin{array}{l}\text { Yes, in biology and physical science, we got a topic } \\
\text { called conservation which is the last topic in the syllabus. } \\
\text { It deals with how to conserve water; animals and species } \\
\text { like endanger species (Penni). }\end{array}$ \\
\hline $\begin{array}{l}\text { Integrating ESD } \\
\text { within the existing } \\
\text { subjects }\end{array}$ & $\begin{array}{l}\text { Desy, Lily, } \\
\text { Moris, } \\
\text { Penni, } \\
\text { Pea Don }\end{array}$ & $\begin{array}{l}\text { It is better that ESD is taught across the curriculum. } \\
\text { Offering ESD on its own may overload the curriculum } \\
\text { and the timetable. So infusing it into other subjects will } \\
\text { be safe to the curriculum and the schools especially the } \\
\text { timetable. Teaching and learning materials such as books } \\
\text { may also be needed (Moris). }\end{array}$ \\
\hline $\begin{array}{l}\text { Integrating ESD as } \\
\text { an independent } \\
\text { subject }\end{array}$ & Oli, Don, & $\begin{array}{l}\text { I think it will be more beneficially if it (ESD) is a subject } \\
\text { on its own because it will be given enough teaching time. } \\
\text { Now, teachers are just sort of browse through these } \\
\text { topics and they are not given the kind of attention they } \\
\text { deserve (Oli). }\end{array}$ \\
\hline
\end{tabular}

All teachers acknowledged the teaching of topics that led to sustainability in their subject. Such topics include, among others, sustainable development, environmental issues, nature conservation, tourism, social justice, and gender issues. To some extent, they were aware what they were supposed to contribute to their own teaching (Borg et al., 2014). However, the complexity of sustainable development issues might not have been understood (Corney, 2006; Spiropoulou et al., 2007). Desy, Lily, Moris, Don, and Pea were positive about the integration of ESD within the existing subjects (cf., Green \& Somerville, 2015). They feared that if ESD was offered as a separate subject, there 
would be too many subjects in the curriculum. Therefore, in order to avoid overloading the timetable, they felt that ESD should be integrated into the existing subjects (Borg et al., 2014; Uitto \& Saloranta, 2017). Oli, Don, Pius and Radon suggested that ESD should be taught as an independent subject. They argued that in this way ESD could be taught effectively, and that a fair assessment was given to it.

Most teachers felt that infusing ESD into the existing subjects saved time on the timetable and did not need a new teacher as well as teaching resources. They also sensed that the framework would ensure that the curriculum remained unchanged. They argued that having ESD as a subject on its own could overload the curriculum and the timetable, the concern about the need for new teachers and teaching and learning materials was in line with Kimaryo (2011). To summarise, ESD within existing subjects and ESD as an independent subject were jointly acknowledged.

\section{Teachers' Teaching Practices in Implementing ESD into the Curriculum}

Teachers' interview responses were classified into three categories as teachers' training in ESD, teachers' teaching methods to ESD, and the involvement of learners in other activities to strengthen the importance of ESD in schools. The teachers' interviews were followed by lesson observation to see how teachers integrate ESD into practice.

All teachers indicated that they did not attend any training on ESD: "No, I did not have any training" (Desy); "Not at all, I have to improvise on that one" (Oli). It is clear that teachers teach partly something that they are not knowledgeable and do not know how to teach it (cf., Borg et al., 2014). Thus, teachers were asked to describe how they became knowledgeable about ESD in the second interview. Desy, Lily, Penni, Pius and Oli said that they came to know about ESD issues from the syllabi of the subjects that they taught. "I learned ESD from interpreting the syllabus of the subject that I teach. Like the topic that I taught a week ago about meiosis, meiosis is a form of cell division and when the cell is dividing it is continuous hence it is sustainable" (Penni). Oli shared similar sentiment but added that he also learned about ESD through media. Oli stated, "Through the media, it is something that I watch on TV, came across it on the Internet, read it in the newspapers, heard it from conferences on SD and perhaps, not on ESD specifically. I got much connected when I began to teach the science subjects. Some of the topics especially the last topic in the syllabus touches on resources and how to utilise them wisely. That is how I became knowledgeable about ESD" (Oli). Radon was of the opinion that he learned more on ESD issues during the conference that he attended and also through studying geography as a major subject during his teacher training.

Although teachers did not attend any training, they were able to grasp ESD knowledge in various ways, which enabled them to integrate ESD into their teaching (cf., Borg et al., 2014; Corney, 2006; Green \& Somerville, 2015; Spiropoulou et al., 2007). Desy, Lily, Penni, Pius and Oli gained their ESD understanding from interpreting their subjects' syllabi. For Oli and Radon, the use of media and conference attendance contributed a lot to their ESD background.

From the teachers' interview responses, it emerged that teachers used participatory methods to teach ESD (Table 4). Teachers' participatory teaching methods are limited to discovery, fieldwork, brainstorming and discussion (cf., Huckle, 2006; Ketlhoilwe, 2007; 2010; Scoullos 2013; Sterling, 2001). The fieldwork method includes the use of school ground and community (Corney \& Reid, 2007; Gayford, 2003; Jeronen et al., 
2017 ) in order to enable learners to interact with the environment and learn in real life. Teachers also reasoned that apart from what learners got in classrooms, they also needed to familiarise themselves with their school ground and environment. They believed that interacting with people and observing things within the local environment would ensure learners' deep understanding of issues studied. None of the teachers made reference to the use of non-participatory methods in teaching ESD.

Table 4

Teachers' Teaching Methods from Interviews

\begin{tabular}{|c|c|c|}
\hline Methods (interview) & Teachers & Some teachers' examples \\
\hline Discovery & Pea, Moris & $\begin{array}{l}\text { I send learners to go find information from newspapers } \\
\text { because there is a lot of important information about the } \\
\text { environment. I also want learners to learn by themselves } \\
\text { and know that what they are studying is about current } \\
\text { issues (Pea). }\end{array}$ \\
\hline Fieldwork & $\begin{array}{l}\text { Oli, Don, } \\
\text { Penni }\end{array}$ & $\begin{array}{l}\text { Mhh, that is a bit challenging because I am not really } \\
\text { trained as such. But sometimes, I use field trips, not really } \\
\text { going far from the school. It is a very good way of teaching } \\
\text { environmental topics because learners learn more on things } \\
\text { that they see and get first-hand experiences on whatever } \\
\text { they are learning out there (Don). }\end{array}$ \\
\hline Brainstorming & Lily & $\begin{array}{l}\text { I ask learners to brainstorm environmental topics for dis- } \\
\text { cussion. I opt for this method because our Namibian educ- } \\
\text { ation system is saying that we should focus on learner- } \\
\text { centred education. We should not see our learners as } \\
\text { empty vessels in class. The learner-centred education is } \\
\text { the reason why I use this method (Lily). }\end{array}$ \\
\hline Discussion & $\begin{array}{l}\text { Desy, } \\
\text { Radon, } \\
\text { Pius }\end{array}$ & $\begin{array}{l}\text { I let learners write essays about environmental issues such } \\
\text { as drought, deforestation, desertification, the use of natural } \\
\text { resources and how they can be sustained and discuss them } \\
\text { in class. I want learners to be aware about the importance } \\
\text { of the environment and their surroundings. (Pius). }\end{array}$ \\
\hline
\end{tabular}

Although teachers indicated that they used participatory methods in integrating ESD into their teaching, this was not evident from the lesson observations made. In actual teaching, teachers only used lecture, question and answer, demonstration and peer-presentation methods. Demonstration and peer-presentation methods were the least used methods.

It can be deduced that teachers did not use any of the methods that they said they used in the interviews during the actual teaching. Observation revealed that the lecture method was used by all teachers. All teachers, except Moris, also used questions and answers where questions were the main mode through which the content was discussed with learners. Demonstration method was used by two teachers (Lily and Oli) and peer presentation method was only used by one teacher (Oli).

Teachers described the methods they used as participatory methods. These methods are likely to enable learners to develop, express and justify their own views about sustainability and also help them make the link between school learning and daily life (Scoullos, 2013). Teachers indicated that to enable learners to learn in real-life and gain 
first-hand experiences, they took their learners to field trips within their local environments or elsewhere (Corney \& Reid, 2007; Jeronen et al., 2017; Ketlhoilwe, 2010; Kimaryo, 2011). They believed that the use of participatory methods such as brainstorming among others would enhance learners' participation in class and generate lots of ideas from the learners as it invited learners to participate. The use of participatory methods was implemented by the learner-centred approach adopted by the Namibian education system. Teachers' idea supported the view that learners came with wealth of knowledge that they gained over the years from interacting with the environment and with others, which could not be ignored (Ketlhoilwe, 2010).

\section{Barriers to the Effective Implementation of ESD}

Barriers faced by teachers include lack of learners' motivation, time constraints, unavailability of teaching and learning materials, lack of teachers' training and limited ESD content in some syllabi (Table 5).

Table 5

Teachers' Teaching Methods from Observations

\begin{tabular}{lll}
\hline Methods (Observation) & \multicolumn{1}{c}{ Teacher } & \multicolumn{1}{c}{ Description } \\
\hline Lecture & All teachers & Teachers explained the lesson content to the learners. \\
\hline Question and answer & $\begin{array}{l}\text { All teachers } \\
\text { except } \\
\text { Moris }\end{array}$ & $\begin{array}{l}\text { Peas asked: what is meant by traditional education? } \\
\text { Learners answered: the type of education that takes } \\
\text { place at home. }\end{array}$ \\
\hline Demonstration & Lily and Oli & $\begin{array}{l}\text { Lily demonstrated steps on how oral examinations are } \\
\text { being conducted by making use of one learner from the } \\
\text { class. The teacher first did a warm up and development } \\
\text { for } 5 \text { minutes before going into the main idea of the } \\
\text { card which is titled deforestation. }\end{array}$ \\
& & $\begin{array}{l}\text { Learners presented their topics as expected by the } \\
\text { teacher. }\end{array}$ \\
\hline Peer presentation & Oli &
\end{tabular}

Lack of learners' motivation can also be a result of lack of awareness and interest in the environment on the side of the learners (Majumdar, 2012). The finding suggests that learners' motivation is very crucial for their own learning and that it is important that learners are made aware of and actively involved in sustainability practices concerning environmental and developmental issues so as to boost their intrinsic motivation. Teachers were mostly concerned about the teaching time and the attention ESD topics were gaining from schools teachers. They felt that most of the topics required more time as learners needed to engage in practical activities and hand-on experiences. However, they sensed that the teaching time allocated to each subject was very limited and did not allow for these types of activities (Corney, 2006; Dube, 2012; Hartsell, 2006; Kanyimba, 2002; Simasiku 2012; Summers et al., 2005). Teachers also felt that the time was not enough for them to engage learners in participatory learning (cf., Dube, 2012; Majumdar, 2012).

Lack of teaching and learning materials was also identified as one of the barriers (cf., Iliško et al., 2011; Summers et al., 2005). Radon stated that a lack of materials in schools was attributed to the fact that there was a lack of fund in many schools. Radon 
and Penni felt that textbooks should be available for both teachers and learners. The results can be supported because to teachers, textbooks are the only readily and most important materials as they were developed in line with the syllabus. However, the use of textbooks as teaching and learning resources may hinder the effective implementation of ESD because using the textbook can be more teacher-centred. Lack of training was identified by teachers. They felt that they were not competent to teach ESD since they were never trained to do so (Borg et al., 2014; Corney, 2006; Kimaryo, 2011; Ortega \& Fuentes, 2015; Uitto \& Saloranta, 2017; Velasquez et al., 2005).

Table 6

Barriers Faced by Teachers in Implementing Education for Sustainable Development

\begin{tabular}{|c|c|c|}
\hline Categories & Teachers & Teachers' examples \\
\hline $\begin{array}{l}\text { ELack of learners' } \\
\text { motivation }\end{array}$ & Oli, Don & $\begin{array}{l}\text { To get learners interested about the idea of ESD is a } \\
\text { challenge, because I do not think there is evidence that } \\
\text { the environment is being damaged. To convince them } \\
\text { that it is important to take care of the environment as } \\
\text { the country is moving forward is a challenge. That is } \\
\text { why I came up with the idea of debating on environ- } \\
\text { mental issues just to get learners motivated and be } \\
\text { enthusiastic about ESD (Oli). }\end{array}$ \\
\hline
\end{tabular}

Limited time alloc- Moris, We have many objectives on these (EE) topics that require ation Don, Pius us to take learners for field trips. For us to go on field trips, we only get 3 days from the region. And for one to explain throughout while in the journey, it takes much time. So, this means that one has to drive straight to the planned site and omit to explain to learners things that are observed throughout the journey. So, time is limited (Moris).

\begin{tabular}{lll}
\hline $\begin{array}{l}\text { Lack of teaching and } \\
\text { learning materials }\end{array}$ & $\begin{array}{l}\text { Pius, } \\
\text { Radon }\end{array}$ & $\begin{array}{l}\text { Ya, we do not have enough textbooks. We also have } \\
\text { financial problems that sometimes in the clubs, we want } \\
\text { to buy cameras and video machines to make use of them } \\
\text { to record whatever we are doing (Radon). }\end{array}$ \\
\hline $\begin{array}{l}\text { Limited content/ } \\
\text { Unclear syllabi }\end{array}$ & Lily & $\begin{array}{l}\text { There are challenges in my perception especially when } \\
\text { it comes to English as subject. There is no indication } \\
\text { that you have to teach about these topics on ESD, unless } \\
\text { it is only from the teacher where you have to use your } \\
\text { creativity (Lily). }\end{array}$ \\
\hline $\begin{array}{l}\text { Lack of teachers' } \\
\text { training }\end{array}$ & $\begin{array}{l}\text { Penni, } \\
\text { Desy, Pea }\end{array}$ & $\begin{array}{l}\text { To me integrating ESD is a challenge because I did not } \\
\text { get any training so in the end I may have little inform- } \\
\text { ation that will not be able to cater for the learners (Penni). }\end{array}$ \\
\hline
\end{tabular}

Teachers were also asked to describe other activities they involved their learners in order to promote ESD. Six of the teachers, Desy, Lily, Pea, Oli, Don, and Radon, said that they involved their learners in school cleaning campaigns. Desy, Moris, Pea, Don and Radon noted that their learners were involved in tree planting activities, while Don involved his learners in environmental auditing. All teachers acknowledged having involved their learners in activities other than those in the curriculum to promote sustainable practices in schools. 


\section{Differences in Teachers' Perceptions on ESD}

It emerged from the present study that the way teachers perceived ESD influenced their teaching practices. Figure 1 summarises the study findings on teachers' perceptions of ESD and the teachers' teaching practices and how they influence each other in the implementation of the school curriculum. It is illustrated that the teachers' perceptions of ESD vary from teacher to teacher (Fraser et al., 2015; Olsson et al., 2016; Sund, 2016).

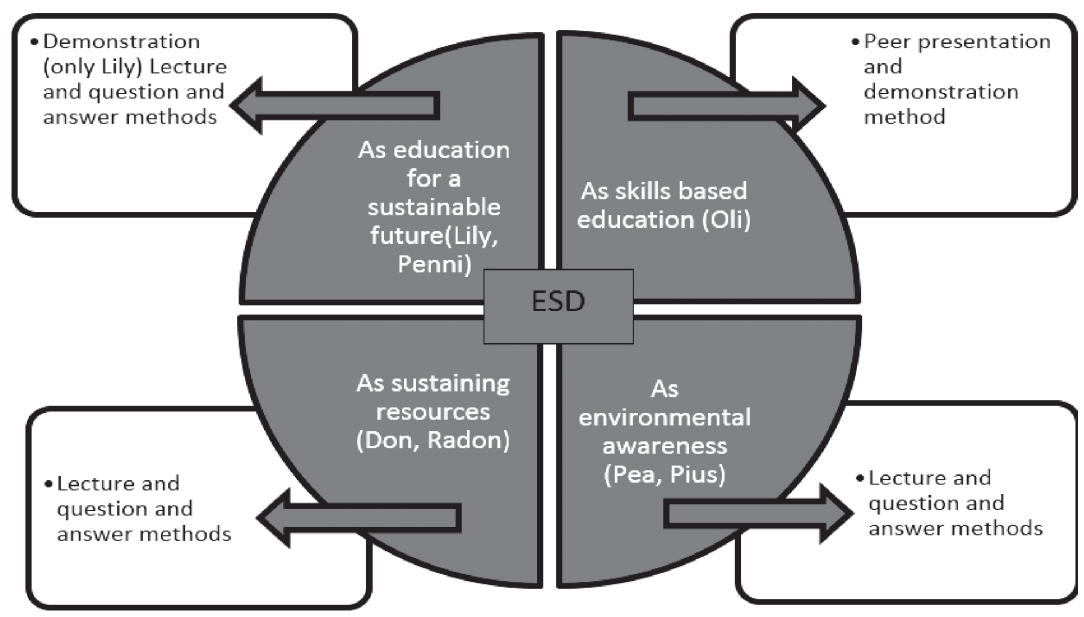

Figure 1. Influences of teachers' perceptions of ESD (interviews) into their teaching practices (observations)

It can be said that nearly all teachers can be classified as those who perceive ESD as teaching about the fragility of the environment and its resources and its importance to the future generations. These teachers demonstrated a lack of understanding of the importance ESD places on developing people's values and attitudes necessary for the development of a sustainable and caring use of the environment for their benefits and that of the future. This may result in a relatively narrow end product, typically involving the learning of specific knowledge and skills.

One teacher (Oli) can be classified as one who perceives ESD as a process of involving learners in taking actions towards the environment. This teacher is likely to take learners for excursions to enable them to have first-hand experiences, use problem solving, demonstration, presentation and decision-making methods. This may result in a broader end product where learners take responsibility for their own learning.

\section{Conclusions}

The present study has attempted to explore Namibian teachers' perceptions of the implementation of ESD and the teachers' teaching practices. The findings of the research may be of interest to school and university educators and should be considered when developing the ESD in Namibia and around the world. The results showed that teachers were familiar with the concept of sustainable development. They described ESD mainly in terms of creating environmental awareness to ensure the sustainable use of natural resources. Regarding the implementation of ESD, all teachers acknowledged the integr- 
ation of ESD into their subjects and school curriculum to respond to the challenges of sustainability in order to improve the quality of the environment. Some teachers suggested that ESD should be taught as an independent subject so that it could be effectively implemented. They argued that this was the only way to ensure that sustainable development issues were dealt with in depth. Other teachers acknowledged and were positive about the integration of ESD into the existing subjects. There is a universal need for the knowledge-competent teacher with a holistic view who can handle multidisciplinary complexity of ESD (see, e.g., Dimenäs \& Alexandersson, 2012).

A teacher, who sees ESD as education in which environmental values and attitudes are explored through direct interaction that promote active learning, is likely to use participatory active approaches to ensure learners' involvement. These methods allow learners to take responsibility for their own learning and act morally and effectively in preserving the environment as they learn through hand-on experiences. These experiences enable reflection and the development of critical awareness and concern about the environment. In this way, the learners' success may be broad: comprehending texts, learning how to learn, developing collaborative skills, and improving well-being. As a result, this allows for greater understanding that leads to the development of various skills to ensure enhancement of learning outcome.

Barriers such as a lack of learners' motivation, time constrain, a lack of teaching and learning materials were identified by teachers. They believe that with these barriers they are unable to implement ESD successfully; hence, there is a need for ESD training. Such training will equip teachers with the necessary knowledge and skills that will help them understand the complexity of sustainable development issues and their interrelations (cf., Iliško et al., 2011).

Although the results of the study like other qualitative studies cannot be generalized beyond its context, it seems that the findings are contextually and socially important for African counties to manage the diversity of their economies and environmental problems in future. Technology is also playing a more important role in African education. Although there are many industrial challenges for African countries, for example, Nigerian teachers are dissatisfied with the absence of infrastructure and ICT equipment (Ololube et al., 2008).

Advisory teachers/subject advisors are the main source of teachers' professional support in Namibia. Future studies should be conducted on advisory teachers to find out how they support and what kind of support they provide to teachers regarding the integration of ESD into the teaching of their subjects. The same study will also reveal how advisory teachers monitor the implementation of ESD in the school curriculum in comparison with teachers who were not trained to teach ESD. Student teachers should be made aware of sustainable development issues and aspects before they embark upon their teaching responsibility. It is therefore suggested that a study being conducted with UNAM the main teacher education institute in Namibia to find out how it ensures that these teachers are being trained and prepared to implement ESD in schools. The student teachers' perceptions about their readiness of implementing ESD in schools will shed more light on how the teacher education curriculum can be reoriented to ensure student teachers are prepared enough to teach according to ESD approaches. Similar study can also be conducted with the primary and junior secondary teachers.

The present study has shown that even with availability of local resources it is not enough to prepare teachers to transfer their perceptions into practical activities. Thus, 
there is a need for longitudinal studies and holistic curriculum development to further explore and overcome teachers' internal and personal barriers and pedagogical knowledge.

\section{References}

Abdulwali, H. A., Alshmrani, S. M., \& Almufti, A. N. (2017). Secondary school science teachers' views about their reflective practices. Journal of Teacher Education for Sustainablity, 19(1), 45-53. doi: 10.2478/jtes-2014-0005.

Alampei, I., Malotidi, V., Psallidas, V., \& Scoullos, M. (2013). Key concepts in Education for Sustainable Development (ESD). In Education for Sustainable Development in Biosphere Reserves and other Designated Areas A Resource Book for Educators in South-Eastern Europe and the Mediterranean. UNESCO.

Bell, J. (2010). Doing your research project. A guide for first-time research. Bershire: McGraw-Hill International.

Biasutti, M., De Baz, T., \& Alshawa, H. (2016). Assessing the infusion of sustainable principles into university curriculum. Journal of Teacher Education for Sustainability, 18(2), 21-40. doi: 10.1515/jtes-2016-0012.

Borg, C., Gericke, N., Höglund, H. O., \& Bergman, E. (2014). Subject-and experiencebound differences in teachers' conceptual understanding of sustainable development. Environmental Education Research, 20(4), 526-551.

Burton, N., Brundrett, M., \& Jones, M. (2008). Doing your educational research project. London: Sage.

Cantrell, D. C. (1993). Alternative paradigms in environmental education research: The interpretive perspective. Alternative Paradigms in Environmental Education Research, 8, 81-104.

Carban, E., \& Fisher, D. 2017. Sustainability reporting at schools: challenges and benefits. Journal of Teacher Education for Sustainability, 19(1), 69-81. doi: 10.1515/jtes2017-0005.

Cohen, L., Manion, L., \& Morrison, K. (2011). Research methods in education. (7th Ed.). London: Routledge.

Corney, G. (2006). Education for sustainable development: An empirical study of the tensions and challenges faced by geography student teachers. International Research in Geographical and Environmental Education, 15(3), 224-240.

Corney, G., \& Reid, A. (2007). Student teachers' learning about subject matter and pedagogy in education for sustainable development. Environmental Education Research, 13(1), 33-54.

Creswell, J. (2009). Research design: Quantitative, qualitative, and mixed methods approaches (3rd Ed.). Los Angeles: Sage.

Denzin, N., \& Lincoln, Y. (2008). Collecting and interpreting qualitative materials (Vol. 3). Thousand Oaks: Sage.

Dimenäs, J. \& Alexandersson, M. (2012). Crossing disciplinary borders: perspectives on learning about sustainable development. Journal of Teacher Education for Sustainability, 14(1), 5-19. doi: 10.2478/v10099-012-0001-0.

Dube, C. (2012). Implementing education for sustainable development: The role of Geography in South African secondary schools. PhD dissertation, Stellenbosch University. 
Egne, R. M. (2014). Representations of the Ethiopian multicultural society in secondary teacher education curricula. Journal of Teacher Education for Sustainability, 16(1), 54-75. doi: 10.2478/jtes-2014-0003.

Flick, U. (2007). Designing qualitative research: The sage qualitative research kit. Thousand Oaks, CA: Sage.

Fraser, J., Gupta, R., \& Krasny, M.E. (2015). Practitioners' perspectives on the purpose of environmental education. Environmental Education Research, 21(5), 777-800.

Gayford, C. (2003). Learning for sustainability: from the pupils' perspective. Retrieved December 3, 2017, from http://www.se-ed.co.uk/sites/default/files/resources/WWF $\%$ 20Learning_for_sustainability.pdf

van Gejeka, N. (2013). Research into learning process in a vocational secondary school in the context of sustainable development. Journal of Teacher Education for Sustainability, 15(2), 67-77. doi: 10.2478/jtes-2013-0012.

Green, M., \& Somerville, M. (2015). Sustainability education: researching practice in primary schools. Environmental Education Research, 21(6), 832-845.

Hartsell, B. (2006). Teaching toward compassion: Environmental values education for secondary students. The Journal of Secondary Gifted Education, 17, 265-271.

Huckle, J. (2006). Education for sustainable development: A briefing paper for the training and development agency for school. London: Earthscan.

Hungerford, H. R. (2010). Environmental Education (EE) for 21st century: where have we been? Where are we now? Where are we headed? Journal of Environmental Education, 41(1), 1-6.

Iliško, D. H., Ignatjeva, S., \& Mičule, I. (2011). Teacher-carried research as a tool for teachers' professional growth. Journal of Teacher Education for Sustainability, 13(2), 87-103. doi: 10.2478/v10099-011-0016-y.

Jeronen, E., Palmberg, I., \& Yli-Panula, E. (2017). Teaching methods in biology education and sustainability education including outdoor education for promoting sustainability - a literature review. Educational Sciences, 7(1). doi: 10.3390/educsci 7010001.

Kabadayi, A. (2016). A suggested in-service training model based on Turkish preschool teachers, conceptions for sustainable development. Journal of Teacher Education for Sustainability, 18(1), 5-15. doi: 10.1515/jtse-2016-0001.

Kanyimba, A. T. (2002). Towards the incorporation of environmental education in the Namibian secondary school curriculum. Masters dissertation, University of South Africa.

Kasanda, C., Lubben, F., Gaoseb, N., Kandjeo-Marenga, M., Kapenda, H., \& Campbel, B. (2005). The role of everyday context in learner-centred teaching: The practice in Namibia secondary schools. International Journal of Science Education, 27, 1805-1823.

Ketlhoilwe, M. J. (2007). Genesis of environmental education policy in Botswana: construction and interpretation. Doctoral dissertation, Rhodes University.

Ketlhoilwe, M. P. (2010). Education for sustainable development in higher education institutions in southern Africa. International Journal of Scientific Research in Education, 3(3), 141-150.

Kimaryo, L. A. (2011). Integrating environmental education in primary school education in Tanzania: teachers' perceptions and teaching practices. Åbo, Finland: Ảbo Akademi University Press. 
Kostova, Z., \& Atasoy, E. (2008). Methods of successful learning in environmental education. Journal of Theory and Practice in Education, 4(1), 49-78.

Littledyke, M. (2008). Science education for environmental awareness: Approaches to integrating cognitive and affective domains. Environmental Education Research, 14(1), 1-17.

Majumdar, S. (2012). Integrating sustainable development in TVET curriculum. In 11th UNESCO-APEID International Conference on "Reinventing Higher Education: Toward Participatory and Sustainable Development” Bangkok, Thailand.

Mweti, I., \& van Wyk, H. (2005). NSSC Development Studies. Module 2. Cambridge: Cambridge University Press.

Namibia. Ministry of Basic Education, Sport and Culture. (1997). Broad Curriculum for Secondary Schools. Okahandja: NIED.

Nigatu, T. (2009). Qualitative data analysis. Retrieved December 3, 2017, from http://www.slideshare.net/tilahunigatu/qualitative-data-analysis-11895136

Ololube, N. P., Egbezor, D. E., \& Kpolovie, P. J. (2008). Education policies and teacher education programs: Meeting the millennium development goals. Journal of Teacher Education for Sustainability, 9, 21-34. doi: 10.2478/v10099-009-0016-3.

Olsson, D., Gericke, N., \& Chang Rundgren, S.-N. (2016). The effect of implementation of education for sustainable development in Swedish compulsory schools - Assessing pupils' sustainability consciousness. Environmental Education Research, 22(2), 176202.

Ortega, J. L. G., \& Fuentes, A. R. (2015). Communication skills training in trainee primary school teachers in Spain. Journal of Teacher Education for Sustainability, 17(1), 86-98. doi: 10.1515/jtes-2015-0007.

Reid, A. (2002). Environmental change and sustainable education. In M. Smith (Ed.), Teaching geography in secondary schools (pp. 225-244). London: The Open University.

Scott, S. (2008). Educational research: Quantitative and qualitative and mixed approaches. Boston: Allyn and Bacon.

Scoullos, M. (2013). Education for sustainable development in biosphere reserves and other designated areas. A Resource book for educators in South-Eastern Europe and the Mediterranean. UNESCO.

Simasiku, F. S. (2012). Investigating opportunities for the development of action competence through fieldwork in Namibia Senior Secondary school Geography curriculum. Master's dissertation, Rhodes University.

Spiropoulou, D., Antonakaki, T., Kontaxaki, S., \& Bouras, S. (2007). Primary teachers' literacy and attitudes on education for sustainable development. Journal of Science Education and Technology, 16, 443-450. doi: 10.1007/s10956-007-9061-7.

Spork, H. (1992). Environmental education: A mismatch between theory and practice. Australian Journal of Environmental Education, 8, 147-66.

Sterling. S. (2001). Sustainable education - Putting relationship back into education. Retrieved December 3, 2017, from http://ecommunitied.tafensw.edu.au

Sund, L. (2016). Facing global sustainability issues: Teachers' experiences of their own practices in environmental and sustainability education. Environmental Education Research, 22(6), 788-805. 
Summers, M., Childs, A., \& Corney, G. (2005). Education for sustainable development in initial teacher training: Issues for interdisciplinary collaboration. Environmental Education Research, 11(5), 623-647.

Uitto, A., \& Saloranta, S. 2017. Subject teachers as educators for sustainability: A survey study. Education Sciencies, 7(8). doi: 10.3390/educsci7010008.

UNESCO. (2009). UN Decade of Education for Sustainable Development (2005-2014). Retrieved December 3, 2017, from http://portal.unesco.org/education/en/ev.phpURL_ID=23279\&URL_DO=DO_TOPIC\&URL_SECTION=201.html

Velazquez, L., Munguia, N., \& Sanchez, M. (2005). Deterring sustainability in higher education institutions: An appraisal of the factors which influence sustainability in higher education institution. International Journal of Sustainability in Higher Education, 6(4), 383-391.

Wals, A., E. J. (2011). Learning our way to sustainability. Journal of Education for Sustainable Development, 5(2), 177-186.

Willis, G. B. (2007). Analysis of the cognitive interview in questionaire desing. Understanding qualitative research. Oxford: Oxford University Press.

Yavetz, B., Goldman, D., \& Pe'er, S. (2014). How do preservice teachers perceive 'environment' and its relevance to their area of teaching? Environmental Education Research, 20(3), 354-371.

Yin, R. K. (2003). Case study research design and methods (6th Ed.). London: Sage.

Yin, R. K. (2009). Case study research: Design and methods (4th Ed). Thousand Oaks: Sage. Retrieved December 3, 2017, from https://manyebooks.org/download/Yincase-study-research.pdf

Yin, R. K. (2012). Applications of case study research (3rd Ed.) Thousand Oaks: Sage. Zhang, Y., \& Wildemuth, B. M. (2009). Qualitative analysis of content. Applications of social research methods to questions in information and library science, pp. 308319.

Correspondence concerning this paper should be addressed to Eveline Omagano Anyolo, University of Namibia, Hifikepunye Pohamba Campus, Ondangwa-Oshakati Main Road, Ongwediva, Namibia. Email: eanyolo@unam.na

Correspondence concerning this paper should be addressed to Sirpa Kärkkäinen and Tuula Keinonen, Yliopistokatu 7, 80100 Joensuu, Finland. Email: tuula.keinonen@uef.fi, sirpa.a.karkkainen@uef.fi 